\title{
OUTCOME OF NON-SURGICAL TREATMENT OF MALLET FINGER
}

\section{RESULTADO DO TRATAMENTO NÃO CIRÚRGICO DO DEDO EM MARTELO}

\author{
Stephan Alejandro Dávalos Barrios ${ }^{1}$ (i), Arturo Felipe de Jesús Sosa Serrano ${ }^{2}$ (i), Jorge alberto Gama Herrera ${ }^{2}$ (1), \\ Maria Fernanda Ramírez Berumen ${ }^{1}$ [i], Jose Manuel Pérez atanasio ${ }^{1}$ (i)
}

1. Instituto Mexicano del Seguro Social, Hospital General Regional No. 2 El Marqués, Querétaro, Mexico.

2. Instituto Mexicano del Seguro Social, Hospital de Traumatología Dr. Victorio de la Fuente Narváez, Ciudad de México, Mexico.

\section{ABSTRACT}

Objective: To establish the association between initial and residual angulation of the distal interphalangeal joint (DIJ) in mallet finger treated conservatively. Methods: An observational, prospective, descriptive and analytical research developed with uncomplicated closed mallet finger patients between January and December 2017. A total of two measurements of the DIJ were done, at the initial trauma and 6 weeks after conservative treatment. All measurements were ranked according to the Crawford Classification and Relative Risk was measured. Results: In total, 43 patients were studied, in which $53.48 \%$ of outcomes obtained were excellent. The sample was divided in two groups; one with less than $30^{\circ}$ of DIJ initial angulation, which had $28 \%$ of residual angulation. The second group with more than $30^{\circ}$ presented $72.22 \%$ of residual angulation. The Relative Risk to present a residual angulation in patients that had $30^{\circ}$ of DIJ initial angulation was 2.99 (Cl 95\%) with $p=0.0059$. Conclusion: It is suggested that patients with an initial DIJ angulation more than $30^{\circ}$ are more likely to present residual angulation with conservative treatment. Level of Evidence IV, Case series.

Keywords: Tendons. Finger joint. Follow-up studies. Outcome study. Acquired Hand Deformities.

\section{RESUMO}

Objetivo: Estabelecer a associação entre a angulação inicial e residual da articulação interfalângica distal em casos de dedo em martelo tratados de forma conservadora. Métodos: Estudo observacional, prospectivo, descritivo e analítico desenvolvido com pacientes que apresentavam dedo em martelo fechado, sem complicações, no período de janeiro a dezembro de 2017. Foram realizadas duas medidas na articulação interfalângica distal, no trauma inicial e seis semanas após o tratamento conservador. Todos foram classificados de acordo com a Classificação Crawford e o Risco Relativo (RR) foi calculado. Resultados: Foram estudados 43 pacientes, dos quais $53,48 \%$ apresentaram resultados excelentes. A amostra foi dividida em dois grupos: um com $<30^{\circ}$ de angulação interfalângica distal inicial, com $28 \%$ de angulação residual, e outro com $>30^{\circ}$, apresentando 72,22\% de angulação residual. O risco relativo de apresentar angulação residual em pacientes com $30^{\circ}$ de angulação inicial da articulação interfalângica distal foi de 2,99 (IC 95\%) com um valor de $p=0,0059$. Conclusão: Sugere-se que os pacientes com angulação inicial da articulação interfalângica distal superior a $30^{\circ}$ têm maior probabilidade de apresentar angulação residual com tratamento conservador. Nível de Evidência IV, Série de casos.

Descritores: Tendões. Articulações dos Dedos. Seguimentos. Avaliação de Resultados em Cuidados de Saúde. Deformidades Adquiridas da Mão.

Citation: Dávalos Barrios SA, Sosa Serrano AFJ, Gama Herrera JA, Ramírez Berumen MF, Pérez Atanasio JM. Outcome of non-surgical treatment of mallet finger. Acta Ortop Bras. [online]. 2020;28(4):172-6. Available from URL: http://www.scielo.br/aob.

\section{INTRODUCTION}

The extensor mechanisms of fingers, hand and wrist are extremely intricated. ${ }^{1-3}$ The terminal tendon injury of the extensor mechanism is referred as mallet finger (MF) deformity. ${ }^{3-6}$

Epidemiologically, this is a common injury with an international prevalence of $9.3 \%$ among all tendinous injuries in the body, and incidence of $5.6 \%$ among all hand and wrist tendinous injuries. ${ }^{7,8}$
There are many studies that have concluded that the recommendation is to immobilize the affected region from six to eight weeks. Nevertheless, there is no evidence of superiority if the splint is placed in a volar or dorsal position. 1,5,6,9,10,11-14

Surgical treatment is controversial in closed MF, but it is indicated in open and fracture associated injuries..$^{15-17}$

In 1984, Crawford described a widely used therapeutic assessment method in four stages: excellent, good, average and poor results. ${ }^{15-18}$

All authors declare no potential conflict of interest related to this article.

The study was conducted at Instituto Mexicano del Seguro Social, Hospital de Traumatología Dr. Victorio de la Fuente Narváez, Unidad Médica de Alta Especialidad.

Correspondence: Stephan A. Dávalos. Cto. Universidades II, Ejido La purisima, El Marqués, Querétaro, México, 76090.dr.stephan.davalos@gmail.com 
Another classification was described by Albertoni who divides the injury according to results from a lateral X-ray of the DIJ, and categorizes it into four types: A, B, C and D. Each type is subdivided into 1 and $2 .{ }^{19}$ Type $A$ is a pure tendinous injury and Type $B$ is an injury with bone avulsion. ${ }^{19}$ In types $A$ and $B$, subtype 1 is described as an injury with less than $30^{\circ}$ and subtype 2 by a flexion deformity greater or equal to $30^{\circ} .19$ Deformities greater than this point of angulation can occur possibly due to damage to the retinacular ligaments and capsular structures in types A2 and B2. ${ }^{19}$ Type C is subdivided into C1, congruent joint (stable), and C2, sub-dislocated or dislocated joint (unstable). Type D is subdivided into D1, epiphyseal detachment (Salter and Harris lesion type 1) and D2, fracture-detachment (Salter and Harris type 3). ${ }^{20}$

In order to support Albertoni's description and to reproduce his findings we tried to determine which degree of DIJ is necessary to achieve excellent result with a splint for closed MF. If such value is determined, we will be able to reduce prolonged incapacity and obtain optimal results for patients with this injury.

Our aim was to determine the initial DIJ angulation, in which the Relative Risk (RR) increased in a statistically significant manner to present residual angulation after conservative treatment. Second, we aimed to identify the most affected hand, finger, gender and age group in our population.

\section{MATERIALS AND METHODS}

\section{Study design}

Clinical, Observational, Descriptive, Analytical, Prospective and Unicentric research.

\section{Location}

Highly Specialized Medical Unit, Traumatology Hospital "Dr. Victorio de la Fuente Narváez" (Mexican Social Security Institute). Mexico City.

\section{Ethics approval and consent to participate}

Our study does not endanger the patient's integrity in any way (biological, functional or ethical). This research fulfills International and National ethics codes. The study was approved by the Research Ethics Committee (Mexican Social Security Institute). Every patient signed an Informed Consent Form, granting their approval to join the research.

\section{Universe}

Patients with closed MF that arrived to the Emergency Department between January 2017 and December 2017.

Inclusion Criteria

- Age between 18 - 45 years old

- Both genders

- Injury in one finger

- Injury in one hand

- Less than 24 hours of injury evolution

Exclusion Criteria

- Associated injuries (bone, nerve, vessel and/or flexor tendon)

- Comorbidities

Elimination Criteria

- Patients who did not complete follow-up time

- Patients who did not complete treatment

- Patients who modified the treatment

- Patients who have not completed radiological studies

Design and sample

The sampling was non-probabilistic type with consecutive cases. The annual prevalence of closed MF in 2016 in our Hospital
(Reference Center of MF in Mexico City) was 153 cases. Therefore, we used the formula based on the prevalence to estimate a statistically significant sample with a 95\% confidence interval $(\mathrm{Cl})$, and the result was 42.94 patients. Then, 43 patients were recruited for the study.

\section{Data collection}

We identified patients diagnosed with closed MF that met the criteria previously mentioned. First, we obtained a posteroanterior and lateral X-Ray of the affected hand, in which there was no support for the affected hand or finger. Secondly, we determined the DIJ angulation in the lateral X-ray. Then a line was drawn in the middle point of both middle and distal phalanx, in its transverse axis to measure the angulation. After that, we estimated the exact angulation with the digital $X$-ray software

Thus, we placed a volar cast splint to immobilize the DIJ in a hyperextension position for six weeks. Finally, we removed the splint and estimated again the DIJ angulation, comparing initial and final results.

\section{Data analysis}

We classified the patients with the final result after six weeks according to Crawford Criteria (CC). This maneuver supported the estimation of patients' frequency in every stage of the CC. All study variables measured were organized in Table 1. We used the SPSS version 22 to statistically analyze the sample. The variable analysis was carried out with Chi square test to associate them. A calibration point was estimated using a $2 \times 2$ contingency table (Table 2). Therefore, we estimated the RR in which the result is statistically significant. After that, a homogeneity test was measured with chi square comparing age and gender. Finally, the sample was classified in two groups; the first with patients that had an initial DIJ angulation less than thirty degrees; and the second group with more than thirty degrees (Table 2). Relative Risk (RR) was used to determine the probability to develop residual angulation.

\begin{tabular}{c|c|c|c|c|c|c|c|c}
\multicolumn{2}{l}{ Table 1. Study variables. } \\
\hline & Name & Gender & Age & $\begin{array}{c}\text { Affected } \\
\text { hand }\end{array}$ & $\begin{array}{c}\text { Affected } \\
\text { finger }\end{array}$ & $\begin{array}{c}\text { Initial } \\
\text { angulation }\end{array}$ & $\begin{array}{c}\text { Final } \\
\text { angulation }\end{array}$ & $\begin{array}{c}\text { Crawford } \\
\text { classification }\end{array}$ \\
\hline 1 & RMM & Male & 43 & Left & V & 12.56 & 0 & Excellent \\
\hline 2 & BJM & Female & 40 & Left & IV & 12.94 & 0 & Excellent \\
\hline 3 & MSJ & Male & 44 & Right & IV & 13.08 & 0 & Excellent \\
\hline 4 & RMJ & Male & 25 & Right & III & 13.16 & 0 & Excellent \\
\hline 5 & GMO & Male & 18 & Right & IV & 14.55 & 0 & Excellent \\
\hline 6 & LTJ & Male & 42 & Left & III & 14.57 & 12.83 & Average \\
\hline 7 & HCM & Male & 23 & Right & V & 14.76 & 11.57 & Average \\
\hline 8 & RGA & Female & 42 & Left & IV & 15.23 & 19.84 & Average \\
\hline 9 & PMC & Male & 25 & Right & IV & 18.13 & 0 & Excellent \\
\hline 10 & LPM & Male & 43 & Right & IV & 18.62 & 0 & Excellent \\
\hline 11 & SRL & Male & 44 & Right & III & 18.63 & 0 & Excellent \\
\hline 12 & SSD & Male & 24 & Left & IV & 20.74 & 0 & Excellent \\
\hline 13 & CGL & Male & 22 & Left & II & 21.19 & 0 & Excellent \\
\hline 14 & IBL & Female & 40 & Right & II & 21.26 & 4 & Good \\
\hline 15 & ROR & Male & 35 & Right & III & 21.46 & 0 & Excellent \\
\hline 16 & LGM & Male & 37 & Right & III & 21.93 & 0 & Excellent \\
\hline 17 & AGJ & Female & 34 & Left & V & 22.8 & 0 & Excellent \\
\hline 18 & MOR & Male & 26 & Left & V & 23.28 & 0 & Excellent \\
\hline 19 & GRA & Female & 40 & Right & III & 23.49 & 7.21 & Good \\
\hline 20 & TAJ & Female & 43 & Right & III & 24.37 & 16.49 & Average \\
\hline 21 & BBD & Male & 44 & Right & V & 24.84 & 16.13 & Average \\
\hline 22 & SRS & Male & 20 & Right & V & 24.87 & 0 & Excellent \\
\hline
\end{tabular}


Table 1. Study variables.

\begin{tabular}{c|c|c|c|c|c|c|c|c}
\hline & Name & Gender & Age & $\begin{array}{c}\text { Affected } \\
\text { hand }\end{array}$ & $\begin{array}{c}\text { Affected } \\
\text { finger }\end{array}$ & $\begin{array}{c}\text { Initial } \\
\text { angulation }\end{array}$ & $\begin{array}{c}\text { Final } \\
\text { angulation }\end{array}$ & $\begin{array}{c}\text { Crawford } \\
\text { classification }\end{array}$ \\
\hline 23 & IBF & Male & 38 & Right & V & 25.12 & 0 & Excellent \\
\hline 24 & LHL & Female & 44 & Right & IV & 26.79 & 0 & Excellent \\
\hline 25 & VTG & Male & 42 & Left & III & 27.26 & 0 & Excellent \\
\hline 26 & VAL & Male & 44 & Left & V & 31.08 & 9.88 & Good \\
\hline 27 & RLR & Male & 36 & Right & V & 32.75 & 0 & Excellent \\
\hline 28 & MAS & Male & 39 & Right & III & 32.99 & 5.72 & Good \\
\hline 29 & MRA & Male & 38 & Right & III & 34.08 & 2.11 & Good \\
\hline 30 & BLD & Male & 44 & Right & III & 35.38 & 7.56 & Good \\
\hline 31 & BHA & Male & 45 & Left & IV & 35.53 & 17.08 & Average \\
\hline 32 & ESG & Male & 44 & Left & III & 36.14 & 6.46 & Good \\
\hline 33 & VTO & Female & 44 & Left & III & 36.29 & 14.09 & Average \\
\hline 34 & AMM & Male & 28 & Left & V & 37.15 & 0 & Excellent \\
\hline 35 & ZMJ & Male & 36 & Left & III & 37.27 & 0 & Excellent \\
\hline 36 & HMA & Female & 44 & Left & V & 37.97 & 12.47 & Average \\
\hline 37 & MRC & Male & 39 & Left & III & 40.28 & 7.28 & Good \\
\hline 38 & GGM & Female & 44 & Right & V & 42.13 & 0 & Excellent \\
\hline 39 & TJI & Male & 43 & Right & V & 45.15 & 20.12 & Poor \\
\hline 40 & CEA & Male & 32 & Right & V & 45.71 & 9.23 & Good \\
\hline 41 & ORE & Female & 44 & Right & III & 46.41 & 17.53 & Average \\
\hline 43 & TRL & Male & 44 & Left & IV & 46.5 & 0 & Excellent \\
\hline & GLH & Male & 44 & Right & V & 56.07 & 25.77 & Poor \\
\hline
\end{tabular}

Table $2.2 \times 2$ Contingency Table.

\begin{tabular}{c|c|c|c}
\hline & $>\mathbf{3 0}$ degrees & $<\mathbf{3 0}$ degrees & Total \\
\hline Residual angulation & 13 & 7 & 20 \\
\hline Non-residual angulation & 5 & 18 & 23 \\
\hline Total & 18 & 25 & 43 \\
\hline
\end{tabular}

\section{RESULTS}

Frequency

A total of 43 patients were studied, in which 32 were men and 11 women (Figure 1). 55.8\% were middle-aged patients (between 40 and 45 years). (Figure 2). Of the total, $58.1 \%$ of the sample were injured in the right hand (Figure 3). The most affected finger was the middle one, with $37.2 \%$ (Figure 4). By comparing results between fingers, we observed that the middle finger showed the worst result for treatment (37.5\% excellent result), and ring finger showed the best result (80\% excellent result) (Figure 5).

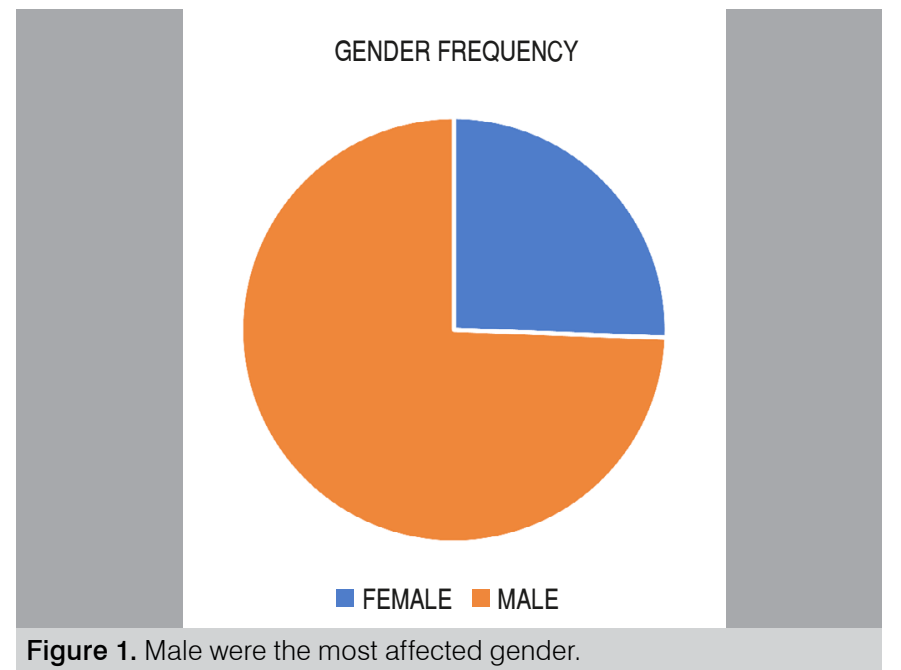

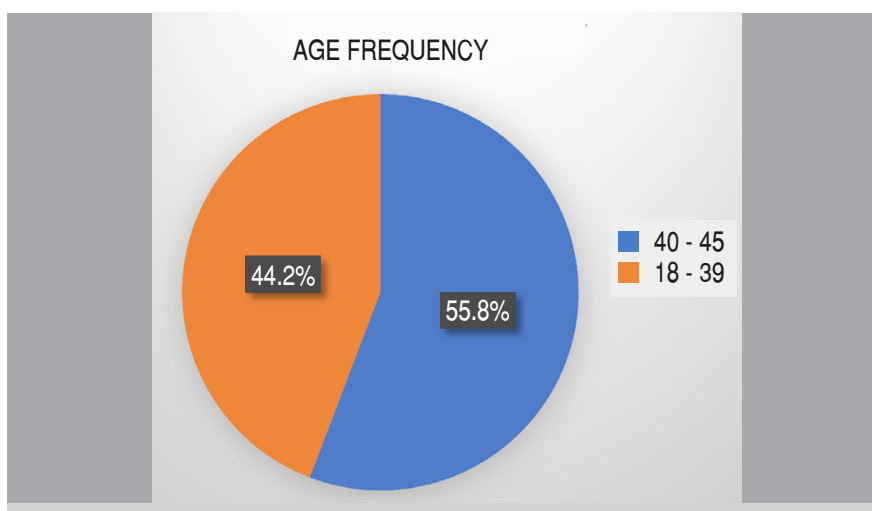

Figure 2. Middle-aged people were the most affected population in our study.

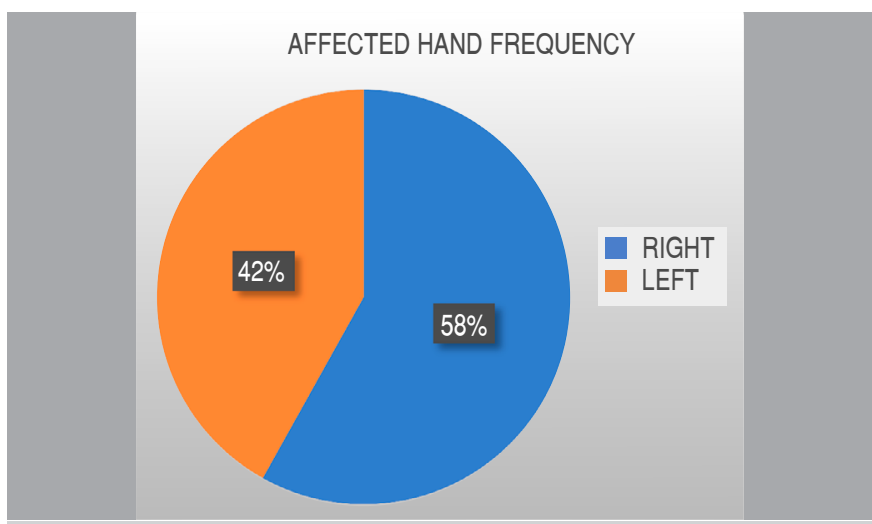

Figure 3. Mallet Finger affects more frequently the right hand.

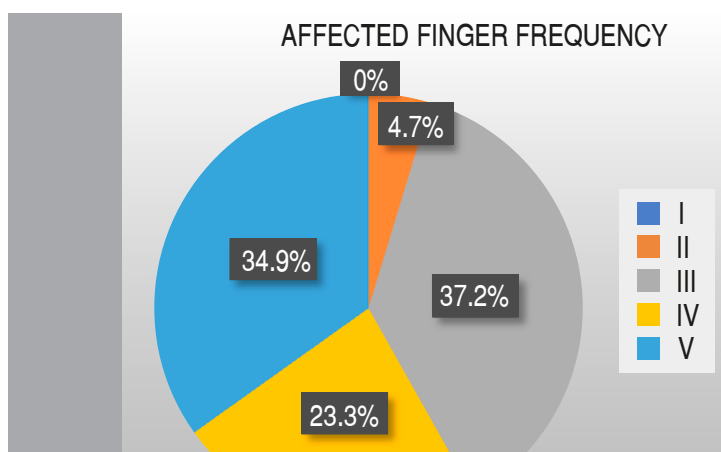

Figure 4. Middle finger was the most frequently affected.

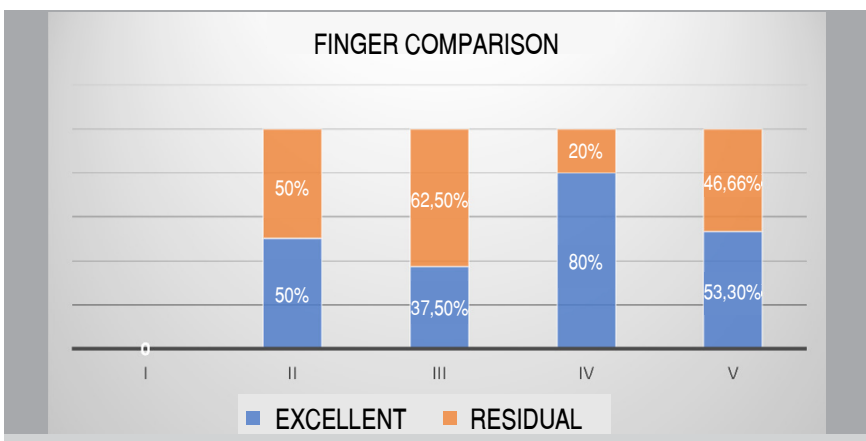

Figure 5. The worst outcome was reported for middle finger. The ring finger had the best results. 


\section{Changes in angulation}

The initial angulation of the DIJ results obtained a mean 28.01, median 24.87, standard deviation 11.18, minimum 13, and maximum 56. The results of Final Angulation were a mean of 5.66, standard deviation 7.41, minimum of 0 , and maximum of 26 .

Crawford Classification: After 6 weeks of treatment the patients were classified according to their results in which $53.48 \%$ were excellent, $20.93 \%$ good, $23.25 \%$ average, and 2.32\% poor. (Figure 6).

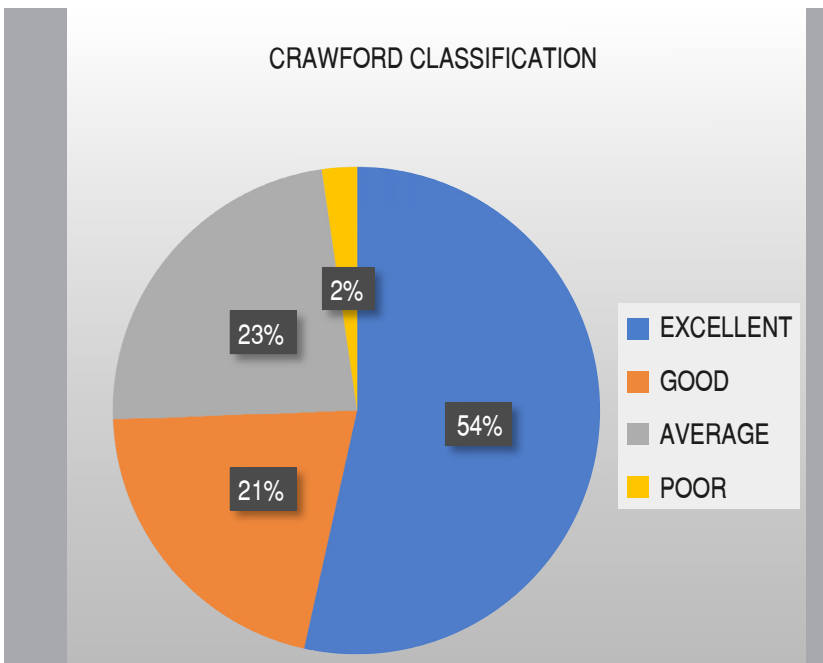

Figure 6. More than half of the sample achieved an excellent result after 6 weeks.

\section{Results by groups}

Statistical tests determined the homogeneity of groups with Chi square test based on age (chi square 0.35; $p=0.66$ ); and gender (chi square $0.18, p=0.55$ ), with no statistical differences.

In the first group, $28 \%$ of the patients developed residual angulation after 6 weeks, compared to the second group which had $72.22 \%$ of residual angulation (Figure 7 and 8).

Our findings show that patients with $30^{\circ}$ of initial angulation, presented RR values as 2.99 (1.73-25.8, IC 95\%, $p=0.0059)$ to develop residual angulation at the end of the conservative treatment. We classified the patient's results based on Albertoni's Classification (Table 3).

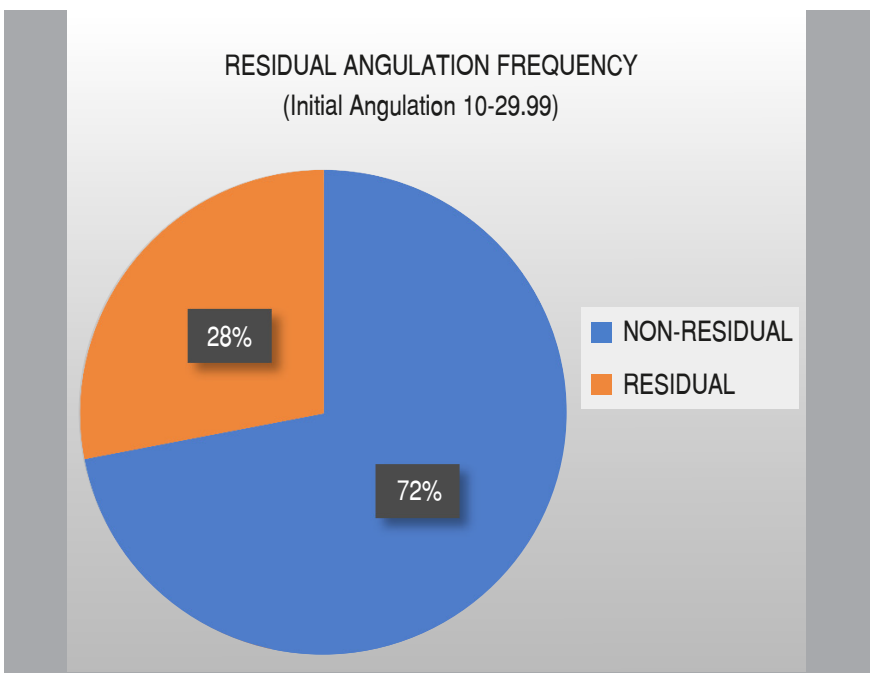

Figure 7. In almost two thirds of the sample, the outcome was no residual angulation in cases with less than 30 of initial angulation of DIJ.

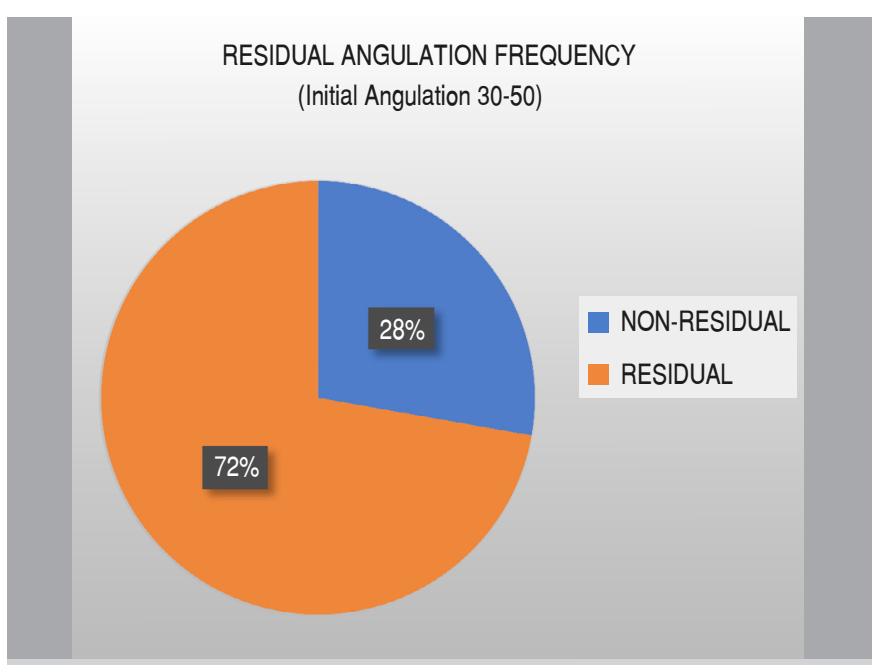

Figure 8. Most residual angulation after 6 weeks occurred in patients with more than $30^{\circ}$ initially.

Table 3. Findings grouped according to Albertoni's Classification.

\begin{tabular}{c|c}
\hline A 1 & A 2 \\
\hline Before Treatment & Before Treatment \\
25 & 18 \\
\hline After Treatment & After Treatment \\
43 & 0 \\
\hline
\end{tabular}

\section{DISCUSSION}

In 2008, Clayton et al. ${ }^{8}$ assessed the distribution of population in a variety of musculoskeletal disorders. They reported the same frequency in gender, age, and most affected hand as our research. Furthermore, they described a populational peak in young adult, fact that can be attributed in greater frequency to hand workers. Altan et al. ${ }^{17}$ in 2014 reported, in the same way that our study, the middle finger as the most affected one. We reported the middle finger as the one who developed the worst outcome comparing with other fingers, this may occur due to the increased frequency of injury in this finger. Notably, our research had a six-week period to compare, since it is the established time to use the splint. Altan's results showed that $66 \%$ of patients achieved an excellent result, in our study this value was $53.48 \%$. This fact probably occur because we did a six-week follow-up and Altan did a follow-up for several months.

In our research, $25 \%$ of patients had a poor outcome, requiring secondary procedures due to a greater angulation of the DIJ that caused functional alterations. Altan mentioned that it is not possible to conclude the time limit for orthosis treatment but this is still controversial.

Our data support the findings of Albertoni in 1980s, claiming that $30^{\circ}$ is the point where mallet finger decreases its possibilities to obtain an excellent result. The Relative Risk to develop residual angulation in patients with an initial DIJ angulation of $30^{\circ}$ was statistically significant.

\section{CONCLUSION}

Thirty degrees in the initial DIPJ angulation is the point where the mallet finger decreases its outcome. Therefore, above this value the probabilities of developing residual angulation after six weeks of conservative treatment in closed mallet finger are increased. The Mexican population has the same epidemiologic frequency in gender, age, most affected hand and finger, as reported worldwide.

\section{ACKNOWLEDGEMENTS}

We thank the Instituto Mexicano del Seguro Social for all the facilities that was given to us in order to develop and finish this research, as well as the nurses, physicians and residents that helped us. 
AUTHORS' CONTRIBUTIONS: Each author contributed individually and significantly to the development of this article. SADB: data research, patient's gathering and treatment, as well as data analysis; AFJSS: reviewed current data about the topic and helped with the data analysis; JAGH: reviewed current data about the topic and helped with the data analysis; MFRB: assisted in the treatment of every patient and also manuscript drafting; JMPA: reviewed the data and made important changes in the manuscript.

\section{REFERENCES}

1. Matzon J, Bozentka D. Extensor tendon injuries. J Hand Surg Am. 2010;35(5):854-61.

2. McMurtry J, Isaacs J. Extensor tendon injuries. Clin Sports Med. 2015;34(1):167-80.

3. Bellemère $P$. Treatment of chronic extensor tendons lesions of the fingers. Chir Main. 2015;34(4):155-81.

4. Posner MA, Green S. Diagnosis and treatment of finger deformities following injuries to the extensor tendon mechanism. Hand Clin. 2013;29(2):269-81.

5. Valdes K, Naughton N, Algar L. Conservative treatment of mallet finger: a systematic review. J Hand Ther. 2015;28(3):237-45.

6. Salazar Botero S, Hidalgo Diaz JJ, Benaïda A, Collon S, Facca S, Livernaux PA. Review of acute traumatic closed mallet finger injuries in adults. Arch Plast Surg 2016;43(2):134-44

7. de Jong JP, Nguyen JT, Sonnema AJ, Nguyen EC, Amadio PC, Moran SL. The incidence of acute traumatic tendon injuries in the hand and wrist: a 10-year population-based study. Clin Orthop Surg. 2014;6(2):196-202.

8. Clayton RA, Court-Brown CM. The epidemiology of musculoskeletal tendinous and ligamentous injuries. Injury. 2008;39(12):1338-44.

9. Facca S, Nonnenmacher J, Liverneaux P. [Treatment of mallet finger with dorsal nail glued splint: retrospective of analysis of 270 cases]. Rev Chir Orthop Reparatrice Appar Mot. 2007;93(7):682-9. French.

10. Gruber JS, Bot AG, Ring D. A prospective randomized controlled trial comparing night splinting with no splinting after treatment of mallet finger. Hand (N Y). 2014;9(2):145-50.
11. Pike J, Mulpuri K, Metzger M, Ng G, Wells N, Goetz T. Blinded, prospective, randomized clinical trial comparing volar, dorsal and custom thermoplastic splinting in treatment of acute mallet finger. J Hand Surg Am. 2010;35(4):580-8.

12. Handoll HHG, Vaghela MV. Interventions for treating mallet finger injuries. Cochrane Database Syst Rev. 2004;(3):CD004574.

13. Nellans KW, Chung KC. Pediatric hand fractures. Hand Clin. 2013;29(4):569-78.

14. Smit JM, Beets MR, Zeebregts CJ, Rood A, Welters CFM. Treatment options for mallet finger: a review. Plast Reconstr Surg. 2010;126(5):1624-9.

15. Alla RS, Deal N, Dempsey IJ. Current concepts: mallet finger. Hand (N Y) 2014;9(2):138-44.

16. Lamaris GA, Matthew MK. The diagnosis and management of mallet finger injuries. Hand (N Y). 2017;12(3):223-8.

17. Altan E, Alp NB, Baser R, Yalçin L. Soft-tissue mallet injuries: a comparison of early and delayed treatment. J Hand Surg Am. 2014;39(10):1982-5.

18. Crawford GP. The molded polythene splint for mallet finger deformities. J Hand Surg Am. 1984;9(2):231-7.

19. Almeida VAS, Fernandes $\mathrm{CH}$, Santos JBG, Schwarz-Fernandes FA, Faloppa F, Albertoni WM. Evaluation of interobserver agreement in Albertoni's classification for mallet finger. Rev Bras Ortop. 2017;53(1):2-9.

20. Albertoni WM. Mallet finger: classification. Rev Hosp Sao Paulo Esc Paul Med 1989;1(3):133-6. 